\title{
Strict and Sloppy Readings of Pronominal Objects in Polish ${ }^{1}$
}

\begin{abstract}
Pronominal clitics in South Slavic languages have been shown to manifest the strict/sloppy reading ambiguity effect. In this paper I examine Polish object pronouns from this perspective, observing that even though they are not clitics, they can still be compatible with the sloppy interpretation if the right type of context is provided. The data speak against an ellipsis-based approach, aligning with the view that the sloppy reading is not a viable test for ellipsis. I thus pursue an alternative analysis on which the strict and sloppy readings are associated with a structural difference in the composition of the pronoun (PersP vs. NumP respectively), offering along the way additional evidence pointing to the importance of pragmatic distinctions in investigations of the interpretive properties of different types of nominal elements. From a more general point of view, the discussion suggests that the empirical picture related to the sloppy interpretation is highly complex, making an investigation of a broader spectrum of languages and contexts indispensable for disentangling all the relevant factors and developing an optimal theoretical approach.
\end{abstract}

\section{Keywords}

strict and sloppy reading, pronouns, clitics, argument drop

\begin{abstract}
Abstrakt
W literaturze dotyczącej języków południowosłowiańskich pokazano, że klityki zaimkowe w tych językach przejawiają dwuznaczność pod względem dokładnej i niedokładnej interpretacji. W artykule poddaję badaniu z tej perspektywy polskie zaimki w funkcji dopełnienia, pokazując, że - pomimo iż nie są klitykami - mogą też mieć interpretację niedokładną, jeżeli są osadzone w odpowiednim kontekście. Dane przemawiają przeciwko
\end{abstract}

${ }^{1}$ This research was supported by National Science Centre, Poland, grant 2018/31/D/ HS2/00130. 
podejściu wykorzystującemu mechanizm elipsy, w zgodzie z poglądem, że interpretacja niedokładna nie jest wiarygodnym testem dla struktur eliptycznych. Proponuję zatem alternatywną analizę, według której interpretacje dokładna i niedokładna wynikają z różnicy strukturalnej zaimka (odpowiednio PersP vs. NumP), dostarczając przy tym dodatkowych danych wskazujących na wagę rozróżnień pragmatycznych dla badań nad własnościami interpretacyjnymi różnych typów jednostek nominalnych. Z bardziej ogólnego punktu widzenia dyskusja sugeruje, że dane empiryczne związane z zagadnieniem interpretacji niedokładnej są niezwykle skomplikowane, przez co konieczne jest zbadanie szerszego spektrum języków i kontekstów w celu rozwikłania wszystkich istotnych zmiennych oraz zaproponowania optymalnego podejścia teoretycznego.

\section{Słowa kluczowe}

dokładna i niedokładna interpretacja, zaimki, klityki, opuszczanie argumentu

\section{Introduction}

The observation that not only elliptical structures, but also overt clitic pronouns can trigger the so-called strict/sloppy reading ambiguity effect is an issue which has received some attention in the literature on Slavic languages. In particular, some of them have been shown to enjoy a much greater freedom in assigning the sloppy reading to an overt pronoun than English, where this is a limited phenomenon. For example, the pronominal dependencies in the Slovenian example in (1) from Perlmutter and Orešnik (1973), quoted here after Franks (2013: 62), can be resolved in two ways: the pronoun ga 'it' can be interpreted either as referring to the same car as the one which Stane saw (strict identity) or to a different one (sloppy identity). ${ }^{2}$
(1) Stane je videl plav avto in tudi Tone ga
Stane Aux seen blue car and also Tone it
je videl. [Slovenian; strict and sloppy]
AUX seen
'Stane saw a blue car and Tone also saw it/one.'

This contrasts with what is observed in Russian, Slovak, and Bulgarian, which make only the strict reading available in this context, as Franks (2013: 62) shows with the examples in (2).

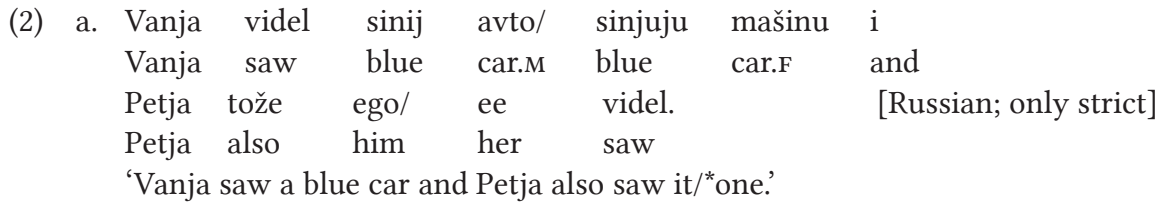

\footnotetext{
${ }^{2}$ Some examples from linguistics sources throughout the text have been adapted to the conventions followed here.
} 
b. Pavol videl modré auto/ modrý automobile i

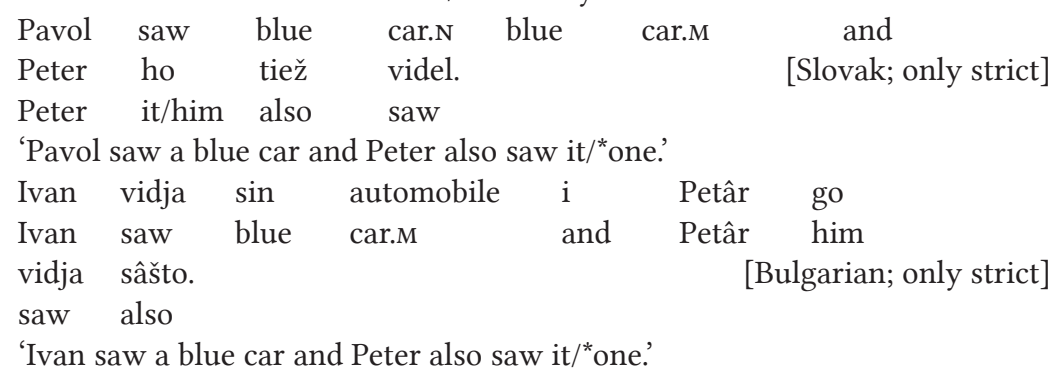

On the other hand, in Bosnian/Croatian/Serbian (henceforth BCS), the judgments are affected by pragmatic plausibility. According to Franks (2013: 76) the sloppy reading is unavailable in the counterpart of (2) in (3), but is required in (4), where the strict reading is pragmatically odd. ${ }^{3}$
(3) Goran je vidio plava kola i Zoran ih je Goran AUX seen blue car and Zoran it AUX također vidio. [BCS; only strict] also seen
'Goran saw a blue car and Zoran also saw it/*ones.'
(4) a. Goran ima smeđi kaput i Zoran ga Goran has brown coat and Zoran him također ima. [BCS; only sloppy] also has
'Goran has a brown coat and Zoran also has *it/one.'
b. Goran ima pametnu ženu i Zoran je Goran has smart wife and Zoran her također ima. [BCS; only sloppy] also has

'Goran has a smart wife and Zoran also has *her/one.'

Even though in these contexts Polish does not make the sloppy reading available, as illustrated in (5) and (6), in Section 2 below I show that this reading is actually not difficult to obtain in some other environments. ${ }^{4}$

${ }^{3}$ Franks (2013) notes that according to Runić (2013) the sloppy reading is generally available in BCS. What is more, an anonymous SPL reviewer points out that factors such as specificity can also influence the interpretive options.

${ }^{4}$ To make the sloppy reading the only plausible option, the example in (5) could be embedded within the context in (i), which, however, does not alter the indicated judgment.

(i) Blue cars are rather rare. Despite this, even though Anna and Zofia live in different cities, yesterday...

The sloppy reading in this context would most naturally be expressed with stripping (... i Zofia też 'and Zofia too'). 
$\begin{array}{llllll}\text { (5) Anna } & \text { zobaczyła } & \text { niebieski } & \text { samochód } & \text { i } & \text { Zofia też } \\ \text { Anna } & \text { saw } & \text { blue } & \text { car } & \text { and } & \begin{array}{l}\text { Zofia also } \\ \text { go }\end{array} \\ \text { zobaczyła. } & & & & \text { [Polish; only strict] } \\ \text { him } & \text { saw } & & & \end{array}$

'Anna saw a blue car and Zofia also saw it.'

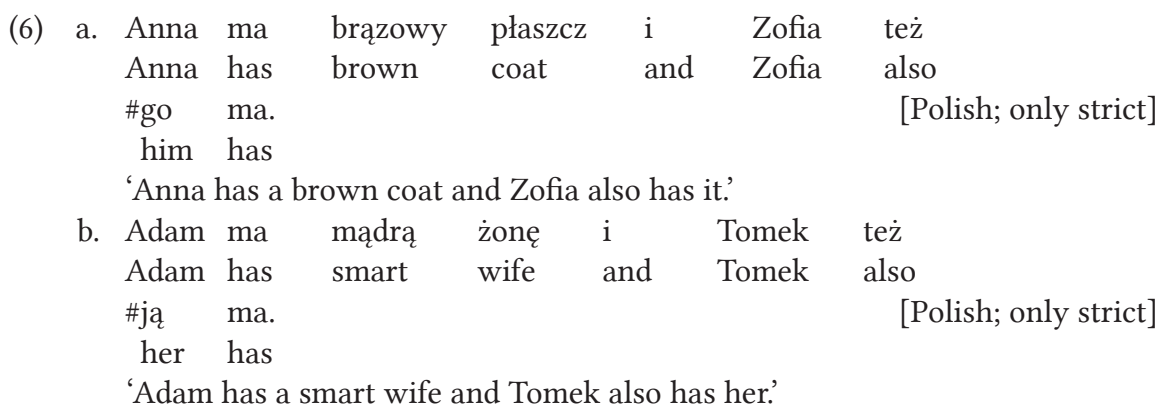

From the theoretical perspective, the availability of the sloppy reading with pronouns in Slovenian and BCS has been approached in different ways. Franks $(2013,2016)$ suggests that under this reading the pronoun originates in the Def(initeness) head and moves to the $\mathrm{K}(\mathrm{ase})$ head in a [K [Def [N]]] structure, in which $\mathrm{N}$ is empty. ${ }^{5}$ Under the strict reading, the pronoun originates under $\mathrm{K}$ in a $[\mathrm{K}[\mathrm{N}]]$ structure. On the other hand, Runić (2013) proposes that the sloppy reading can be attributed to the predicate $(<\mathrm{e}, \mathrm{t}>)$ denotation of clitic pronouns in languages without articles, just as what has been proposed for null arguments in Japanese in Tomioka (2003). ${ }^{6}$ The clitic is then interpreted as property anaphora and its ultimate reading can be

The examples in (6) favour the sloppy reading in their own right and, what transpires from Franks's (2013) discussion is that, unlike in Polish, the sloppy interpretation comes naturally here in BCS without the need for additional context.

${ }^{5}$ This holds of the deficient/clitic pronouns such as ga 'him'. In the full counterpart njega 'HIM' nje- is generated under N and moves to K, which hosts ga. See Franks (2016) for some discussion of the differences and similarities between his approach and Cardinaletti and Starke's (1999) proposal, under which a structural difference is assumed between strong, weak, and clitic pronouns in that the structure of the latter is truncated with respect to the former, and, as follows, different types of pronouns are of different categories $\left(\left[\mathrm{C}_{\mathrm{L}}\left[\Sigma_{\mathrm{L}}\left[\mathrm{I}_{\mathrm{L}}\right]\right]\right]\right.$ vs. $\left[\Sigma_{\mathrm{L}}\left[\mathrm{I}_{\mathrm{L}}\right]\right]$ vs. $\left.\left[\mathrm{I}_{\mathrm{L}}\right]\right)$. For Franks $(2013,2016)$ all pronouns are K(P)s. As I show in Ruda (2021), Polish pronouns do not behave in a way expected under Cardinaletti and Starke's (1999) system, which is why the alternative pursued here is more in line with Franks's approach.

${ }^{6}$ Dating back at least to Huang (1987) and Otani and Whitman (1991) on the VP ellipsis side and to Oku (1998) and Kim (1999) on the argument ellipsis side, the sloppy reading has been at the center of the discussions offering ellipsis-based analyses of null arguments, as opposed to the null pronoun-based approach. For example, the Mandarin structure in (i) from Huang (1991: 64), where the direct object of the verb kanjian-le 'see-PERF' which is missing in the second clause is ambiguous between the strict (i.e. Mary saw John's mother) and the sloppy reading (i.e. Mary saw her own mother), can be argued to involve verb-stranding VP ellipsis, where the overtness of the lexical verb is due to its movement to a higher functional 
achieved by existential closure or by type-shifting via the application $\mathrm{I}$ (see Tomioka 2003 for a more detailed semantic discussion). While the availability of this type of analysis suggests to both Tomioka (2003) and Runić (2013) that employing argument ellipsis to account for the sloppy reading of null arguments is not warranted, in his recent paper Bošković (2018) proposes a different perspective, suggesting that not only is argument ellipsis the right type of approach to the null argument data, but it can also be employed to account for the sloppy reading of BCS clitics. In particular, Bošković (2018) builds his analysis around the observation that both argument ellipsis and clitics make the sloppy reading available and proposes that structures with clitics actually feature clitic doubling with argument ellipsis and it is the elliptical NP which gives rise to the sloppy interpretation. While this is certainly an interesting hypothesis to entertain (see Section 3 for some more discussion), it predicts that only languages with clitics should make the sloppy reading available. This is not true of Polish, which in the right contexts makes the sloppy reading available, as I show in Section 2, but which lacks clitics in its pronominal system (see Cetnarowska 2004, as well as Jung and Migdalski 2015, Migdalski 2016, and Ruda 2021). The facts discussed below will thus show that the complexity of the empirical picture of the availability of the sloppy interpretation with overt pronouns, including the role of information-structural factors, needs to be appreciated more in developing the analyses and that ellipsis may indeed not be the optimal mechanism to derive all relevant observations.

projection before ellipsis applies (see (ia)). Alternatively, only the nominal object can be taken to undergo ellipsis here (see (ib)).

(i) John kanjian-le tade mama, Mary ye John see-PERF his mother Mary also kanjian-le ø. [Mandarin; strict and sloppy] See-PERF

'John saw his mother, and Mary did, too.'

a. ... Mary ye kanjian-le $f_{\mathrm{VP}}$ kanjian le tade mama\}.

b. ... Mary ye kanjian-le $f_{\mathrm{NP}}$ tade mama.

While the strict/sloppy reading ambiguity effect has been used as a diagnostic for the VP or NP/DP ellipsis analysis of data with null arguments in various languages (for relevant discussions of the VP ellipsis approach, see, a.o., Huang 1991; Hoji 1998; Otani and Whitman 1991; Gribanova 2013a, 2013b; Cyrino and Lopes 2016; Bailyn 2017, and Landau 2020; for discussions focusing on the NP/DP ellipsis approach, see Oku 1998; Saito 2007; Şener and Takahashi 2010; Duguine 2014; Landau 2018; Sakamoto 2019, and references therein), the strength of the argument has been weakened by the observation that the sloppy reading is sometimes available outside the domain of ellipsis (see, e.g., Tancredi 1992; Runić 2013, and Merchant 2013). 
I thus begin the discussion in Section 2 with a brief comment about the system of Polish pronouns for some general orientation, after which I move on to probe into the interpretive options available to Polish pronouns in the light of the strict/sloppy reading ambiguity effect. I discuss contexts involving different types of antecedents, including non-quantificational, non-referential, extralinguiatic, and quantificational antecedents. I show that the availability of the sloppy reading is highly sensitive to context in Polish (especially contrast), a feature shared with null objects, and I suggest that the sloppy reading is available in Polish due to the third person pronouns being associated not only with the PersP representation, but also NumP, the latter of which can be interpreted as property anaphora. In Section 3, I consider some further theoretical issues raised by the data. Section 4 concludes.

\section{Strict and sloppy readings of object pronouns in Polish}

In its pronominal inventory, Polish has the full and reduced forms, though only the second person singular and the third person singular masculine show the distinction morphologically (see Witkoś 1998; Cetnarowska 2003, 2004 and references therein). Accordingly, we have the opposition between ciebie 'you.ACc' and cię 'you.ACc' and jego 'him.Acc' and go 'him.ACC', but no alternative is available for mnie 'me.ACC', $j a$ 'her.ACC', je 'it.ACC', nas 'us.ACC', was 'you.PL.ACC', ich 'them.M.ACC', and je 'them.ACC'. The consensus emerging from the literature is that the system of personal pronouns in Polish lacks clitics, both full and reduced variants showing the behaviour of phrasal projections (see Cetnarowska 2004, as well as Jung and Migdalski 2015, Migdalski 2016, and Ruda 2021).

In general, the availability of the sloppy reading of overt pronouns in some Slavic languages has been attributed to two factors: (i) their clitic status, and (ii) the relevant languages being articleless systems (see Runić 2013; Bošković 2018, and references therein). As Polish fulfils the latter condition, but its pronouns do not fulfil the former, it is interesting to observe that the sloppy interpretation is nevertheless available to Polish pronouns under appropriate discourse conditions. The contexts where this is possible are not completely parallel to what has been reported for Slovenian and BCS, among other Slavic languages. ${ }^{7}$ For example, an equivalent of the BCS sentence in (7) from Runić (2013: 420), which according to her yields similar results in

\footnotetext{
${ }^{7}$ The focus here will be on object pronouns. A discussion of pronominal subjects involves additional complications due to the fact that Polish is a consistent null subject language with rich agreement morphology (however defined).
} 
Slovenian, Czech, and Slovak, is not compatible with the sloppy reading in Polish (see also (5)-(6) in Section 1). ${ }^{8}$

(7) [Context: Nikola and Danilo are best friends. They have many interests in common except their taste for movies is completely different. Specifically, Nikola likes comedies, whereas Danilo likes horror movies. In their town, a movie festival of all film genres takes place every summer. A comedy and a horror movie played at the same time in two different buildings. Given their very different tastes, Nikola and Danilo saw two different movies.]

$\begin{array}{lllllll}\text { Nikola } & \text { je } & \text { video } & \text { film, a } & \text { video } & \text { ga } \\ \text { Nikola } & \text { AUx } & \text { saw } & \text { film } & \text { and } & \text { saw } & \text { it.CL.ACC } \\ \text { je } & \text { i } & \text { Danilo. } & & & & \text { [BCS; strict and sloppy] } \\ \text { Aux } & \text { and } & \text { Danilo } & & & & \end{array}$

'Nikola saw a movie and Danilo saw it/one too.'

(8) [Context: Anna and Adam are best friends. Continued as in (7).]

Anna widziała film i Adam też go

Anna saw film and Adam too him

widział.

saw

'Anna saw a movie and Adam saw it too.'

Similarly, unlike in comparable contexts in the Japanese null object structure (see, a.o., Takahashi 2020: 49), the pronoun in (9) does not give rise to ambiguity by which Zofia could have noticed either the same or a different squirrel. Only the former is possible (just as is the case with an overt pronominal object in Japanese). ${ }^{9}$

\begin{tabular}{lllll} 
a. Anna & zauważyła & wiewiórkę. & Zofia & jej \\
Anna & noticed & squirrel & Zofia & her.GEN \\
nie & zauważyła. & & \multicolumn{2}{c}{ [Polish; only strict] } \\
not & noticed & &
\end{tabular}

${ }^{8}$ As Runić (2013) notes, Bulgarian and Macedonian do not make the sloppy reading available here either. Since these two languages have definite articles, Runić (2013) relates these observations by suggesting that the sloppy reading is available only in languages without articles (see also Bošković 2018).

${ }^{9}$ The pronoun in (9a) is genitive due to the Genitive of Negation, obligatory in Polish regardless of semantic factors.

To make the sloppy reading the only plausible option, the examples in (9) and (10) could be embedded within the context in (i), which, however, does not alter the indicated judgment.

(i) Anna and Zofia live in different cities and they both like going for a walk in the nearby forests. Yesterday... 

b. Anna zauważyła wiewiórkę. Zofia też
Anna noticed zquirrel Zofia also
ją zauważyła. [Polish; only strict]
her.ACC noticed
'Anna noticed a squirrel. Zofia also noticed it.'

However, the situation changes when the sentence involves some sort of contrast, as in (10), where both interpretations are available.

$\begin{array}{llllll}\text { (10) Anna } & \text { zauważyła } & \text { wiewiórkę } & \text { przed } & \text { domem. Zofia } \\ \text { Anna } & \text { noticed } & \text { squirrel } & \text { in.front.of } & \text { house } & \text { Zofia } \\ \text { zauważyła } & \text { ją } & \text { w } & \text { lesie. } & & \text { [Polish; strict and sloppy] } \\ \text { noticed } & \text { her } & \text { in } & \text { forest } & & \end{array}$

'Anna noticed a squirrel in front of the house. Zofia noticed it/one in the forest.'

Moreover, due to pragmatics, (11) is actually compatible only with the sloppy interpretation.

(11) Anna oddała życie $\begin{array}{lllll}\text { za swój } & \text { kraj. } & \text { Zofia oddała } \\ \text { Anna gave life } & \text { for self's } & \text { country } & \text { Zofia gave } \\ \text { je ratując tonącego } & \text { brata. } & & \text { [Polish; only sloppy] } \\ \text { it saving drowning } & \text { brother }\end{array}$
'Anna gave her life for her country. Zofia gave hers saving her drowning brother.'

It is thus quite clear that the interpretive properties of Polish pronouns are highly sensitive to context. Following Ruda's (2021) analysis of the representation of Polish pronouns, I suggest that the availability of the sloppy interpretation of pronouns in Polish can be attributed to the third person pronouns having two possible representations, that is PersP and NumP, where the morphological contribution of the Pers head in this case can be null, yielding the same outcome for a third person Pers-Num- $n$ and a Num$n$ structure. In effect, the strict and sloppy readings in (12), where the preference is moderated by pragmatic plausibility, arise as a result of the pronoun je 'them' being represented either as a PersP (only strict reading) or as a NumP (in principle both types of readings, on the assumption that Polish, as an articleless language makes definite interpretations of NumPs available (see Ruda 2021 for more discussion) ${ }^{10}$ ).
(12) a. Anna zarobiła pieniądze, a Adam je Anna earned money and Adam them wygrał. [strict and sloppy] won
'Anna earned money and Adam won some/it.'

\footnotetext{
${ }^{10}$ Principles such as Maximize Presupposition ("Präsupponiere in deinem Beitrag so viel wie möglich!" [Presuppose as much as possible in your contribution!]; Heim 1991: 515) may require PersP to be used in definite contexts rather than NumP).
} 


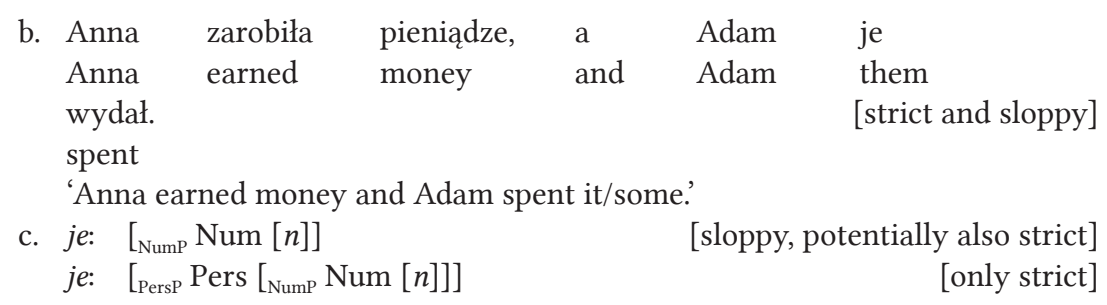

If the pronominal NumP can operate as property anaphora, the sloppy reading is accounted for (cf. Tomioka's 2003 assumptions concerning Japanese null arguments and Runić's 2013 assumptions about BCS clitics, both of whom assume $ı$ type-shifting for definite interpretations, which may not be necessary (see Ruda 2021)).

Setting this inside a broader perspective, it can be noticed that pronouns are not alone in their sensitivity to contextual factors, as these also govern the acceptability and interpretation of null objects in Polish. ${ }^{11}$ This points to the importance of the information-structural configurations in which the acceptability of different options is tested.

While null objects are in principle available in Polish, their distribution is restricted (see Ruda 2017 and references therein). Firstly, there are contexts where a null object is unavailable and the overt pronoun has to be used. For example, as McShane (1999: 61) shows, omitting the object is unacceptable in (13a), but when the contrastive coordinator $a$ 'and' is used instead of $i$ 'and', the judgment changes, as indicated in (13b).

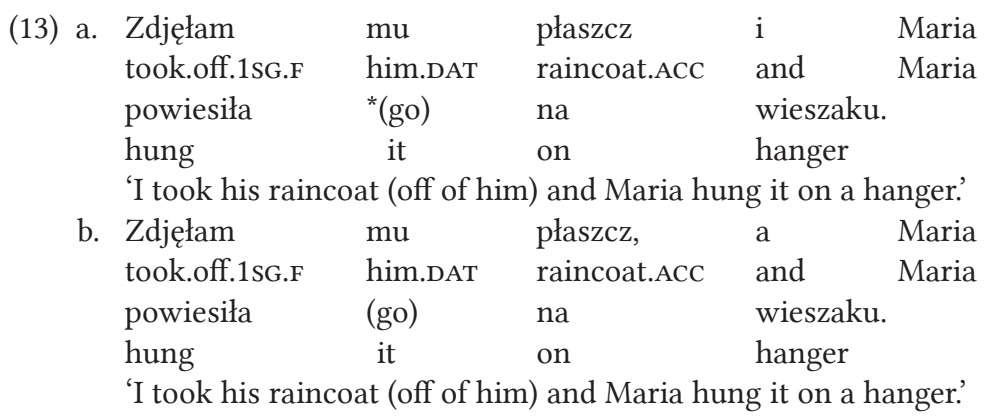

An important factor to bear in mind here is also that there are different structures which can deliver the sloppy reading in Polish, so some degree of competition may also influence the interpretive preferences of the relevant sentences. For example, in the context in (14), a null object is not acceptable. ${ }^{12}$

\footnotetext{
${ }^{11}$ See McShane (1999) for a discussion of different factors influencing object drop in Polish (e.g. contrast and the case-marking of the antecedent).

${ }^{12}$ This example is modeled after Landau (2018: 4), who shows that in Hebrew the null object is available here with the strict and sloppy reading, as opposed to a pronominal object, which requires the former.
} 
An object realised as an overt pronoun triggers the strict reading only, as in (14b). The sloppy reading is rendered with an overt anaphoric pronoun, a remnant of NP-internal ellipsis of swoje biurko 'self's desk' in (14c). Only the VP anaphoric equivalent of the English do so anaphor is ambiguous between the two interpretations, as in (14d).

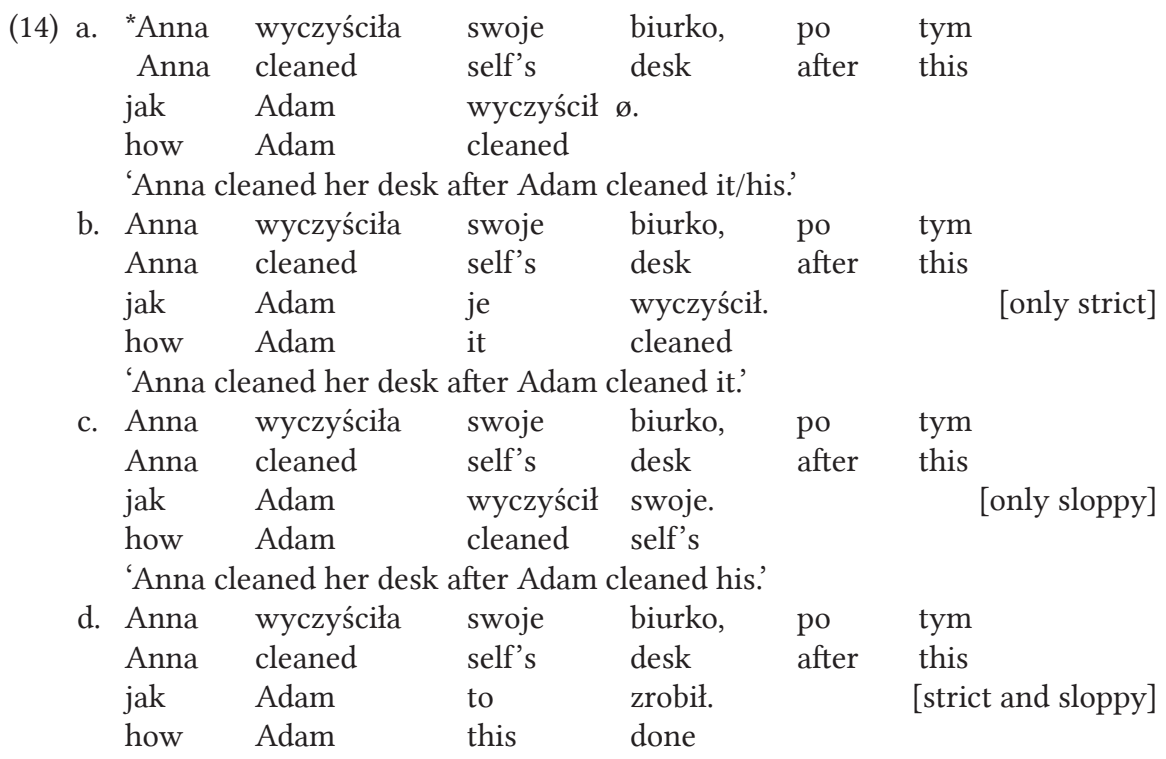

'Anna cleaned her desk after Adam did it.'

Again, the situation changes when contrast is involved, in which case the null object is acceptable. In the context in (15a), the null object has the sloppy reading according to which Adam repainted his new apartment, not Anna's. Using a pronoun in this context makes both interpretations possible and, as expected, using the elliptic NP with the anaphoric remnant introduces only the sloppy interpretation.

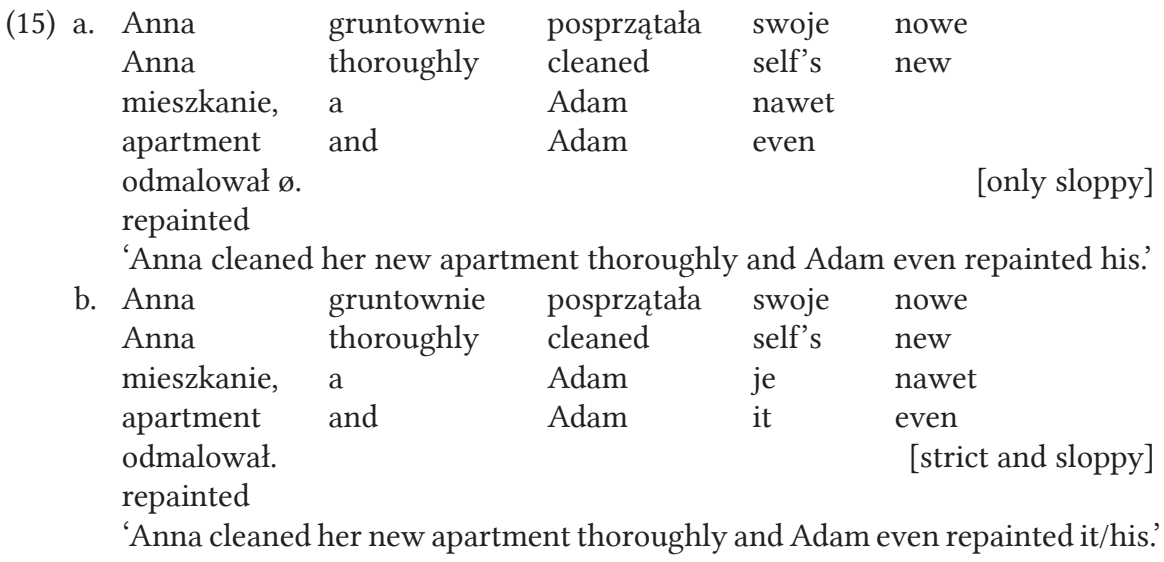




\begin{tabular}{lllll} 
c. Anna & gruntownie & posprzątała & swoje & nowe \\
Anna & thoroughly & $\begin{array}{l}\text { cleaned } \\
\text { self's }\end{array}$ & new \\
mieszkanie, & a & Adam & swoje & nawet \\
apartment & and & Adam & self's & even \\
odmalował. & & & \multicolumn{2}{c}{ [only sloppy] } \\
repainted \\
'Anna cleaned her new apartment thoroughly and Adam even repainted his.'
\end{tabular}

A similar pattern is observed with sentences uttered by different speakers, as in (16a), where the null object yields the sloppy interpretation, (16b), where the pronoun triggers ambiguity, and (16c), where the anaphor is consistent only with the sloppy interpretation.

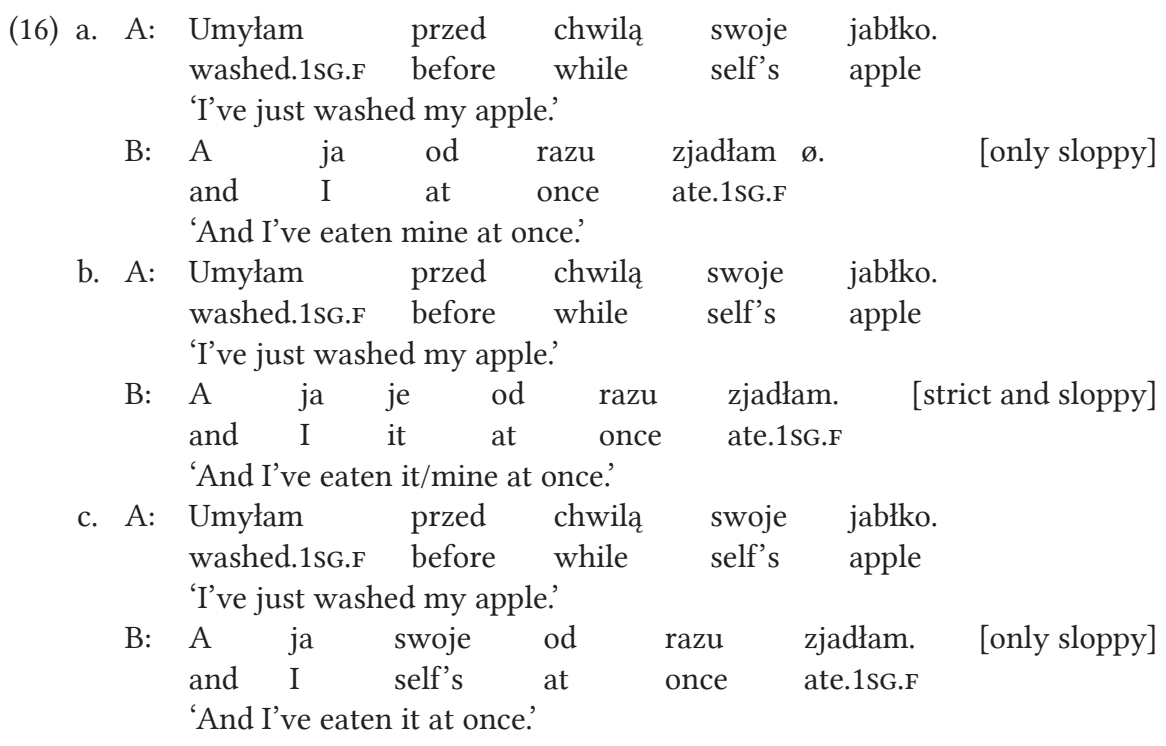

The patterns are similar with human antecedents, as in (17).

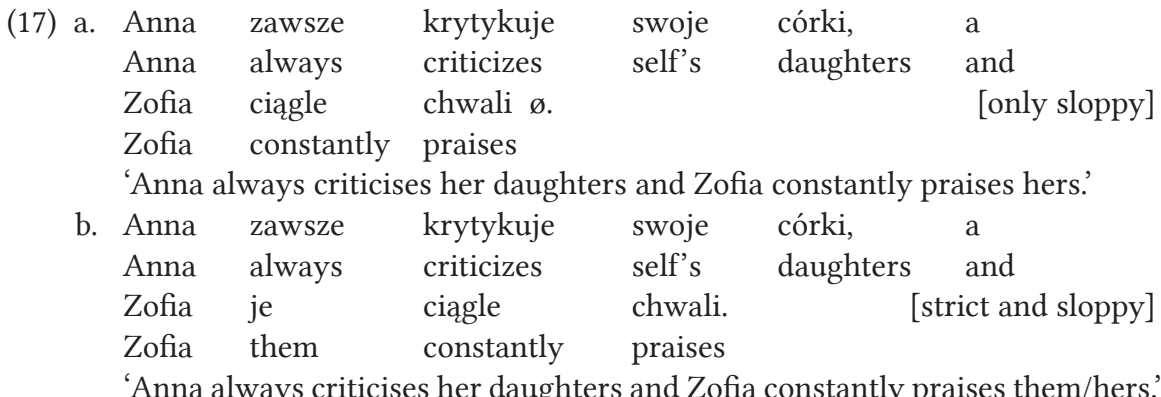




$\begin{array}{llllll}\text { c. Anna } & \text { zawsze } & \text { krytykuje } & \text { swoje córki, } & \text { a } \\ \text { Anna } & \text { always } & \text { criticizes } & \text { self's daughters } & \text { and } \\ \text { Zofia } & \text { swoje } & \text { ciagle } & \text { chwali. } & \text { [only sloppy] } \\ \text { Zofia them } & \text { constantly } & \text { praises } & \\ \text { 'Anna always criticises her daughters and Zofia constantly praises hers.' }\end{array}$

To complete the picture, I show in (18) that the sloppy reading is also available to the indirect object and, as indicated in (19)-(21), it can also be accessed with the morphologically largest forms (i.e. with full pronouns). ${ }^{13}$

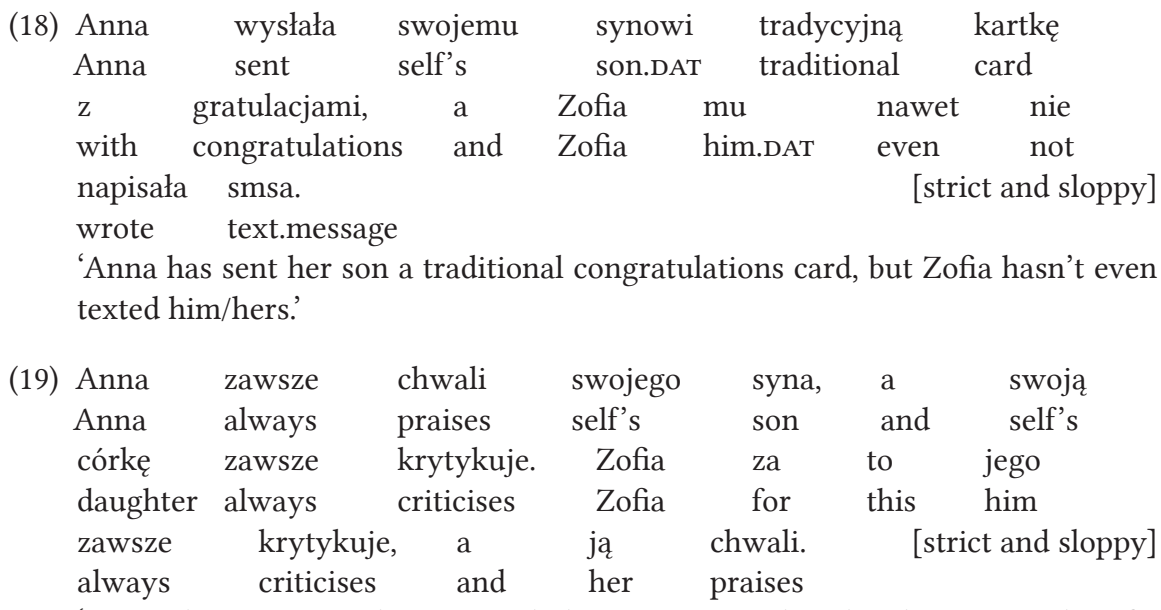

'Anna always praises her son and always criticises her daughter. Instead, Zofia always criticizes him/her son and praises her/her daughter.'
(20) Anna oddała swój pierścionek zaręczynowy jubilerowi
Anna gave self's ring engagement jeweler
do wyczyszczenia. Zofia jego nigdy nawet nie
for cleaning Zofia him never even not
zdejmuje $\mathrm{z} \quad$ palca, chociaż inne pierścionki
takes.off from finger although other rings
też zostawia do czyszczenia. [sloppy]
also leaves for cleaning

'Anna gave her engagement ring to a jeweler for cleaning. Zofia never even takes hers off her finger, although she also leaves other rings for cleaning.'

${ }^{13}$ To make the sloppy reading easily accessible in (18), (19), and (21), the examples can be embedded within the respective contexts in (i)-(iii).

(i) Anna's and Zofia's sons got promoted. Anna has a good relationship with her son, but Zofia doesn't, which is why...

(ii) Anna and Zofia each have a son and a daughter.

(iii) Anna has a great relationship with her father, but Zofia does not. 


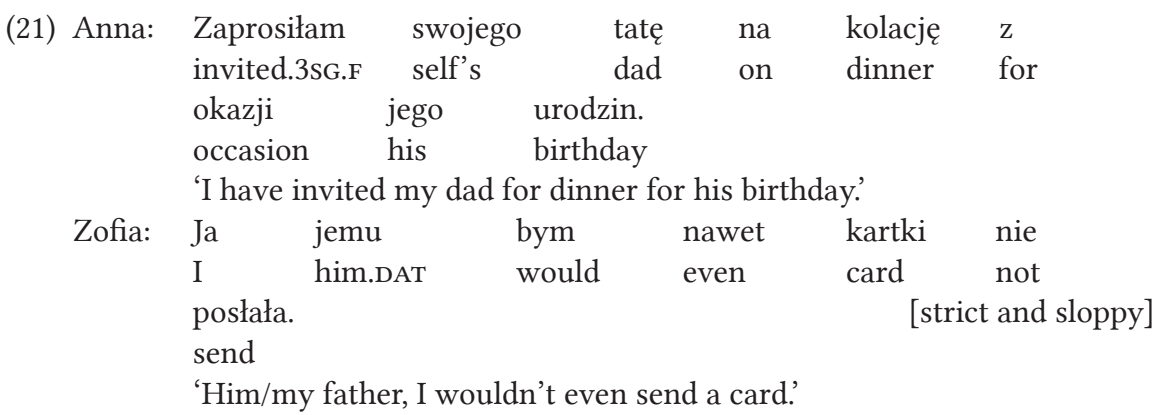

While impossible to explain on an analysis linking the availability of the sloppy interpretation to the clitic status, these data are expected if such interpretation is available to pronominal NumPs, third person pronouns having the NumP representation at their disposal regardless of their morphological complexity on Ruda's (2021) proposal, on which the additional piece of morphology in full pronouns originates below rather than above Num (i.e., in $\sqrt{\text { inside a }}\left[{ }_{\text {NumP }}\right.$ Num $[n \sqrt{ }]$ ] structure).

What is more, this kind of interpretation is available to the pronoun even if the antecedent does not introduce an individual, as in (22) with the nonreferential antecedent Matki 'Mother's', where the pronoun is interpreted as referring to the speaker's mother.

\begin{tabular}{|c|c|c|c|c|c|}
\hline $\begin{array}{l}\text { (22) Dziś } \\
\text { today } \\
\text { do }\end{array}$ & $\begin{array}{l}\text { jest } \\
\text { is } \\
\text { restauracji. } \\
\text { restaurant }\end{array}$ & $\begin{array}{l}\text { Dzień } \\
\text { day }\end{array}$ & $\begin{array}{l}\text { Matki, } \\
\text { mother's }\end{array}$ & $\begin{array}{l}\text { więc } \\
\text { so }\end{array}$ & $\begin{array}{l}\text { zaprosiłam } \\
\text { invited }\end{array}$ \\
\hline
\end{tabular}

Finally, in the absence of a linguistic antecedent both a null object and an overt pronoun can yield the sloppy interpretation, as in (23), modeled after Tomioka's (2014b: 261) null object example from Japanese, which is also acceptable. $^{14}$

${ }^{14}$ Again, it is not the case that the null object is always acceptable in the absence of an overt linguistic antecedent in Polish, even if the non-linguistic antecedent is salient in discourse, as illustrated in (i).

(i) [Context: A sees B striving to squeeze a book into a full backpack.]
A: Nigdy *(jej) tam nie wciśniesz.
never her.gen there not squeeze
'You'll never squeeze it there.'

Note that the feminine pronoun jej 'her.GEN' has to be used here, as dictated by the grammatical gender of the noun ksiażka 'book' in Polish. The relation between the non-linguistic antecedent and the pronoun thus needs to be somehow mediated by the relevant lexical root (and taking into account its combination with an $n$ head bearing the feminine gender feature 
(23) [Context: You and a friend go to the same pottery class, and yesterday you each made your first coffee cup. Today you see your friend drinking coffee out of the one she made, and you say to her...]

Ja swój/ go/ ø podarowałam przyjaciółce.

I self's him gifted.1sG.F friend

'I gifted mine/it (the cup I made) to a friend.'

While a more detailed comparison than the one which can be offered here is due, what the data seem to indicate is that there may be a correlation between the contexts licensing object drop and the sloppy interpretation of pronominal objects in Polish. At first sight this seems to be in line with an approach unifying argument ellipsis and sloppy interpretation, as Bošković (2018) does, but suggesting that object drop in Polish is simply argument ellipsis (understood as full NP deletion at PF or its LF-copying equivalent) does not explain why in a number of cases a null object yields only the sloppy interpretation, in contrast to what is observed in similar cases in East Asian languages, among others, and in contrast to what can be expected on the assumption that a pronoun should be deletable as well (under partial identity with the antecedent; see Oku 1998). ${ }^{15}$

In addition to the sloppy interpretation in the contexts discussed above, quantificational antecedents have also been employed both in discussions of null arguments (see Takahashi 2008 and related work) and interpretive properties of clitics in South Slavic languages (see Runić 2013 and Bošković 2018), the latter of which argue in favour of unifying the two phenomena (via an analysis based on Tomioka's 2003 approach to null arguments in Japanese in Runić and via LF-copying-based argument ellipsis coupled with clitic doubling in Bošković). The next section is thus devoted to this environment.

\subsection{Quantificational antecedents}

As (24) illustrates, the quantificational interpretation is not available to the pronoun in Polish. The pronoun ich 'them' can either refer to the same set of teachers here or it can be understood to refer to teachers in general, the latter interpretation being expected to arise on the current assumptions, on which the pronoun can be interpreted as property anaphora. ${ }^{16}$

on the assumption that gender is encoded in $n$; see Lowenstamm 2008 and Willim 2012), one option being the introduction of the root in the syntactic structure of jej 'her.GEN' in (i) and subsequent deletion along the lines of Sauerland (2007).

${ }^{15}$ In addition to argument ellipsis, deriving (some) object drop patterns from V-stranding VP ellipsis needs to be considered as a viable analytical alternative, especially in light of Merchant's (2018) constatation that verb identity is not required for VP ellipsis to apply. In Ruda (2017) I analyse null objects in Polish as deleted $n(\mathrm{P}) \mathrm{s}$.

${ }^{16}$ These examples are based on parallel null argument Japanese examples from Takahashi (2008) and Şener and Takahashi (2010), where the null object can inherit the quantificational 


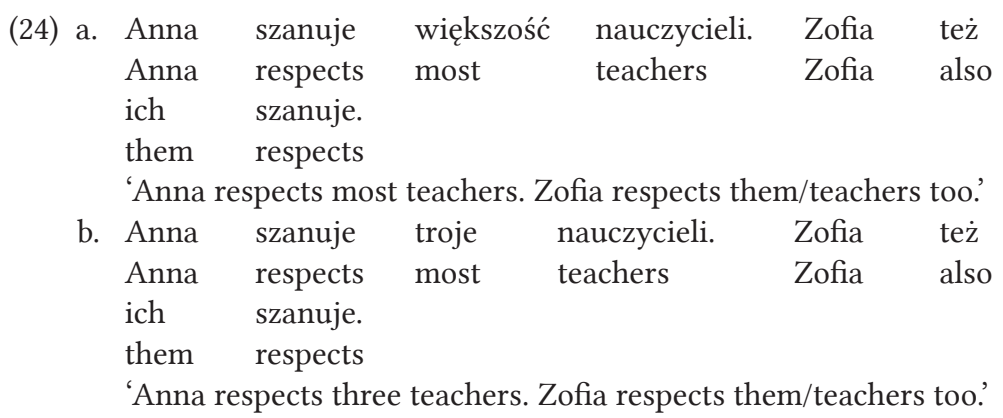

In this case contrast does not help, as shown in (25a), where the pronoun can refer to the same set of journalists, or, more plausibly, to any journalists relevant in the context (i.e., Anna turned out all journalists who came to see her on Wednesday, not only many of them). The second reading is thus similar to the reading in (25b), where the pronoun is accompanied by the quantifier wszystkich 'all'. The quantificational reading derived from the quantifier wielu 'many' in the antecedent is unavailable in (25a), casting doubt on the possibility of applying to Polish the reasoning linking the interpretation of overt pronouns to argument ellipsis. ${ }^{17}$

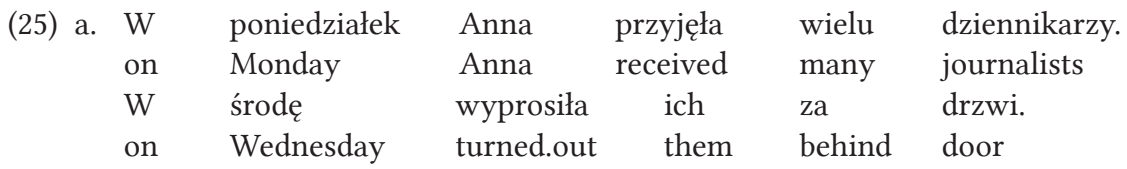

'On Monday Anna received many journalists. On Wednesday she showed them/journalists the door.'

reading of the antecedent. Runić (2013) reports that BCS clitics behave in parallel to Japanese null arguments here and can likewise be interpreted as quantificational (see also Bošković 2018).

However, Tomioka (2014b) points out that structures with numerals frequently used in the literature are not the best test for the sloppy quantificational reading, as they can be analysed as denoting properties. On the other hand, downward-entailing quantifiers, which do not run into this problem, cannot be antecedents to null arguments in Japanese. This contrasts with what is predicted on the argument ellipsis analysis, but can be accounted for under the choice functional analysis of null arguments proposed in Kurafuji (2018), on which null arguments in Japanese are represented as empty NPs in the syntax. In this context in Polish the sloppy (quantificational) interpretation can be achieved by stripping (i.e., Zofia te ż 'Zofia too'). A null object is not acceptable in (24).

${ }^{17}$ To the extent that the null object is acceptable here, it is associated with the quantificational reading of wielu dziennikarzy 'many journalists'. The most natural way to achieve this reading though is through repeating the quantifier and only eliding the following noun or through the use of phrases such as tyle samo 'as many'. 


$\begin{array}{llllll}\text { b. W } & \text { poniedziałek } & \text { Anna } & \text { przyjęła } & \text { wielu dziennikarzy. } \\ \text { on } & \text { Monday } & \text { Anna } & \text { received } & \text { many journalists } \\ \text { W } & \text { środę } & \text { wyprosiła } & \text { ich } & \text { wszystkich } & \text { za } \\ \text { on } & \text { Wednesday } & \text { turned.out } & \text { them } & \text { all } & \text { behind } \\ \text { drzwi. } & & & & & \\ \text { door } & & & & & \end{array}$

'On Monday Anna received many journalists. On Wednesday she showed them all/all journalists the door.'

Another context which suggests that argument ellipsis is not involved in the interpretation of Polish pronouns is provided by the existential quantifier kogos 'someone' in (26) and the n-word nikogo 'nobody' in (27). In the former case, the pronoun picks out the individual whom Anna adores, not just any unspecific person from the editorial office. The n-word in (27a) cannot be interpreted as substituting for the pronoun in the second sentence, which lacks a potential referent in this case, yielding pragmatic ill-formedness. In the modal context introduced in (27b), the pronoun refers to whoever would be hired, if Anna did hire someone. Substituting the pronoun with nikogo 'nobody' would result in unacceptability here, as the n-word needs to be licensed by sentential negation, Polish being a strict negative concord language. ${ }^{18}$

(26)

$\begin{array}{llllll}\text { Anna } & \text { uwielbia } & \text { kogoś } & \mathrm{z} & \text { tej } & \text { redakcji, } \\ \text { Anna } & \text { adores } & \text { someone } & \text { from } & \text { this } & \text { editorial.office } \\ \text { a } & \text { Zofia } & \text { go } & \text { nie } & \text { znosi. } & \\ \text { and } & \text { Zofia } & \text { him } & \text { not } & \text { tolerates } & \end{array}$

'Anna adores someone from this editorial office and Zofia doesn't tolerate him/ this person.'

(27) a. W

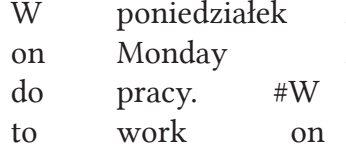

zwolniła.

fired

'On Monday Anna didn't hire anyone. On Wednesday she instead didn't fire him.'

b. W

\begin{tabular}{|c|c|c|c|c|c|}
\hline W & poniedziałek & Anna & nie & przyjęła & nikogo \\
\hline on & Monday & Anna & not & hired & nobody \\
\hline do & pracy. & Musiałaby & go & najpierw & \\
\hline & & woura.nave.lo & nाm & IIrst & \\
\hline & and & on & this & not & time \\
\hline
\end{tabular}

'On Monday Anna didn't hire anyone. She would have to train him/this person first and she hasn't got the time for this.'

\footnotetext{
${ }^{18}$ To the extent that it is acceptable, the null object in the context of (26) has the interpretation of kogos $z$ tej redakcji 'someone from this editorial office'. Similarly, in (27a) the null object would be interpreted as nikogo 'nobody'. Dropping the pronoun in (27b) is unacceptable.
} 
Thus, while overt pronouns can in some contexts receive the sloppy reading in Polish, the patterns observed with quantificational antecedents show clearly that the pronoun is not interpreted in parallel to what we expect to find in contexts of argument ellipsis and the data are thus not similar to argument drop data in languages such as Japanese, in contrast to what Runić (2013) and Bošković (2018) report for BCS and other South Slavic languages.

\section{Further theoretical considerations}

The example in (28) from Runić (2013: 420) further illustrates that BCS clitics can be associated with both the strict and the sloppy reading.

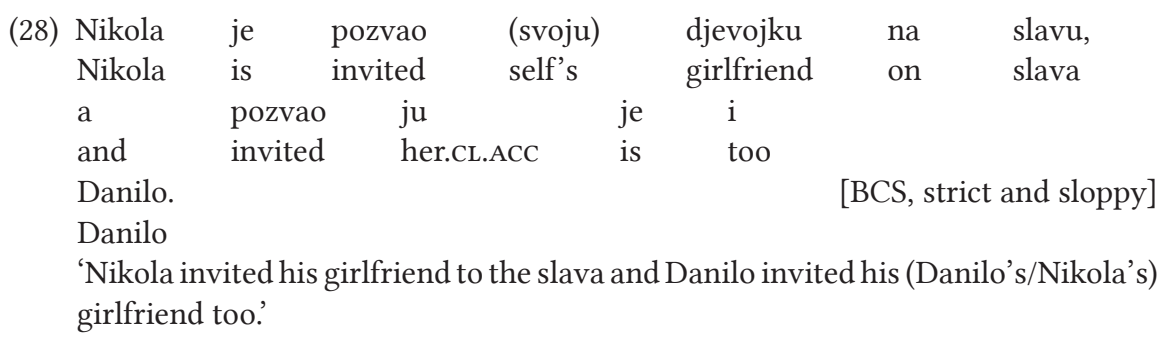

Bošković (2018: 3) notes that the sloppy reading is not available in this context in English, as in (29), and suggests that the relevant difference is in the clitic status of the corresponding pronominal in BCS.

(29) Nikola invited his girlfriend, and Danilo invited her too.

[only strict]

Importantly, it is not the case that clitics can always be associated with the sloppy interpretation. Since in languages such as Macedonian clitics do not make this reading available, Bošković (2018) suggests that an additional factor is at play, namely the presence or absence of articles in a language (the presence or absence of the DP layer; see also Runić 2013). Hence, connecting the hypothesis that argument ellipsis is unavailable in DP languages (Cheng 2013) and the observation that the sloppy reading is unavailable with clitics in such languages leads Bošković (2018) to propose that argument ellipsis is responsible for the sloppy reading with clitics in NP languages. ${ }^{19}$

\footnotetext{
${ }^{19}$ More specifically, building on his 2008 and 2012 proposal that languages are divided into the NP and DP classes, where in the former argumental NPs lack the DP layer and are of type $<\mathrm{e}, \mathrm{t}>$ (undergoing covert type shifting to type $<\mathrm{e}>$ ), whereas in the latter argumental NPs project the DP layer, in which case D is responsible for the $<\mathrm{e}>$ denotation (see Chierchia 1998, and the discussion of the differences between Chierchia's and Bošković's systems in Bošković 2018: fn. 25), Bošković (2018) proposes that only elements of type <e, t> can be
} 
Bošković (2018) follows the LF copying implementation of argument ellipsis (see Oku 1998; Saito 2007), which means that in examples such as (28) above the NP (svoju) djevojku '(self's) girlfriend' is Case-licensed in the first clause and then is copied at LF and inserted into the second clause, where it doubles the clitic. As it does not need to have Case licensed (again), the structure is acceptable, even though regular clitic doubling is mostly unavailable in BCS, as in (30) from Bošković (2018: 15).

$\begin{array}{llll}\text { (30) *Ivan ga piše } & \text { pismo. } \\ \text { Ivan it is.writing } & \text { letter } \\ \text { 'Ivan is writing a/the letter.' } & \end{array}$

Bošković (2018) suggests that prototypical instances of clitic doubling in BCS are unavailable due to Case-licensing issues in that the clitic is assigned Case, which cannot be assigned also to the NP here. As on Saito's (2007) account, which Bošković adopts, argument ellipsis involves LF copying of the NP which has had its Case feature licensed prior to this operation, the LFcopied NPs do not require Case licensing and clitic doubling is possible with argument ellipsis in BCS. Substituting the clitic with a non-clitic pronoun blocks the sloppy reading in BCS, which according to Bošković (2018) is explained if clitics are the only pronoun type which can be accompanied by argument ellipsis, responsible for the sloppy interpretation. This, in turn, follows on the assumption that the relevant structures are represented as clitic doubling structures. Thus, neither (weak/strong) pronouns nor clitics make the sloppy reading available on their own. This reading is rather a direct result of argument ellipsis. When the latter is available, the sloppy reading is observed. When it is not, it is not.

Interesting as it is, Bošković's (2018) proposal poses some non-trivial questions. From the acquisitional perspective, the unavailability of overt clitic doubling in languages which make the sloppy reading available at least in some contexts suggests that this kind of a procedure cannot be acquired based on overt evidence. Furthermore, the proposal does not generalise to languages lacking not only clitic doubling but also pronominal clitics, but still manifesting

targeted by argument ellipsis. Bošković (2018: 23) generalises this into (i), suggesting also that the copying operation applies in the (covert) syntax before type shifting takes place.

(i) Only elements of type $<$ e, $t>$ can be copied in LF.

This accounts for the availability of argument ellipsis only in NP languages, since nominal arguments are of type <e > in DP languages. However, it is unclear how these assumptions can derive argument ellipsis with antecedents realised as CPs, pronouns, proper names, quantifier phrases, and phrases with demonstrative pronouns, which are arguably not of type $<e, t>$. Bošković's approach is also incompatible with Landau's (2018) analysis of Hebrew object drop as argument ellipsis, the language clearly belonging to the DP class. 
the sloppy reading of overt pronouns. The focus here has mostly been on Polish, but the empirical picture is complicated further by the fact that in some contexts even languages such as English make the sloppy reading available. In fact, the availability of the sloppy reading of pronouns in such languages is a reason why Merchant $(2013,2018)$ goes so far as suggesting that such readings should not be used as a diagnostic for ellipsis at all (see also Kasai 2014 and Tomioka 2014a, 2014b). This seems reasonable, since, even though English highly restricts the sloppy reading, as Bošković observes, this reading is clearly available and requires a theoretical account. One approach in this context is to assume, as Bošković does, that two different mechanisms are needed to account for such readings in BCS as opposed to English (and likely Polish). ${ }^{20}$ Another way to proceed is to look for a solution which would be applicable in all contexts and then see how different languages restrict its application. ${ }^{21}$

In addition to data from Polish, which lacks clitics, data from Greek can also pose a challenge to Bošković's (2018) proposal. While Greek has both clitics and overt clitic doubling, it is a language with articles, which Bošković takes to block argument ellipsis, as noted above. Yet, as Merchant (2018: 252) shows, the sloppy reading with pronouns in Greek is much more widely available than in English and it is compatible with different kinds of antecedents (see (31)-(32)).

(31) 0

$\begin{array}{ll}\mathrm{O} & \text { Alexandros } \\ \text { the } & \text { Alexandros }\end{array}$

afu because Pavlos. Pavlos

'Alexandros did his best because Pavlos did.'

(32)

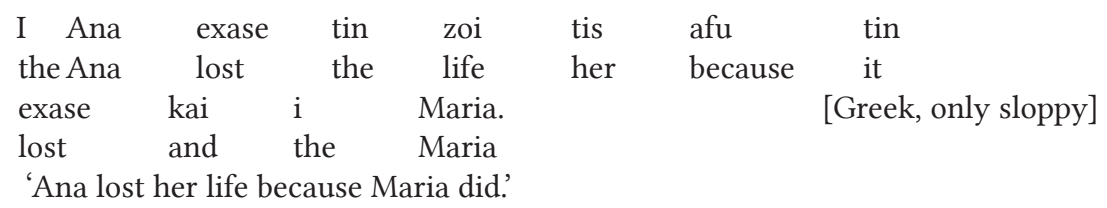

${ }^{20}$ This holds even if the sloppy reading in English is analysed as NP deletion, as in Elbourne (2005, 2013), as here only a subpart of the argument is deleted, not its full maximal projection.

${ }^{21}$ These restrictions can in fact be different for different types of what we can collectively call the sloppy reading in a single language. One relevant avenue of research would thus be to also consider paycheck, donkey etc. contexts in BCS, where there appear to be intriguing requirements in terms of grammatical and semantic gender matching between the pronoun and the antecedent (see Wechsler 2006).

An anonymous reviewer suggests that there may be a significant correlation between the lack of articles and the availability of sloppy readings. However, as also Greek and English pronouns can have sloppy reading, as shown later in the text, examining the putative correlation needs further work, which is beyond the scope of this paper. 
In this context English blocks the sloppy reading, as in (33), suggesting that perhaps English is special in imposing very strict restrictions on the availability of the sloppy reading, whereas it is languages such as Slovenian and BCS which should be viewed as baseline.

(33) a. Arnold lost his life in the war, but before he lost it, he had written a letter to his mother.

b. Arnold lost his life in the war, and \#Bernard lost it, too.

Interestingly, features such as the singular/plural distinction and inalienable possession play a role in the availability of the sloppy reading in English, as in (34) and (35) from Tomioka (2014b: 253-254).

(34) a. Johnny worships his father, but Bobby finds him annoying.

[ ${ }^{*}$ sloppy]

b. Johnny loves his grandparents, but Bobby finds them overbearing.

[??sloppy]

c. Professor A treats his students with respect, but Professor B treat them like idiots.

[ ${ }^{\mathrm{OK}}$ sloppy]

(35) a. Bertha writes her papers by herself, but Carla usually co-authors them with others.

[?sloppy]

b. Johnny lost his virginity at 18 , and Timmy lost it at 20 .

[ ${ }^{\mathrm{OK}}$ sloppy]

These data point to the relevance of semantic and pragmatic factors, similarly to what has been suggested by Franks (2013) with respect to the sloppy reading of clitics in BCS and what is clearly found in Polish as well. This pertains not only to the interpretation of pronouns, but also bare NPs in Slavic languages in general, whose discourse anaphoric, paycheck and donkey anaphoric uses are likewise affected by contrast (see Ruda 2021 for some examples). The data discussed throughout this paper thus show that contrast influences the availability and interpretation of different kinds of nominal expressions in Polish (sloppy readings of pronouns, null object licensing), though potentially other factors in need of further investigation may have a role to play as well.

\section{Conclusion}

Investigating the properties of Polish personal pronouns from the perspective of the strict/sloppy reading ambiguity, I have shown that the availability of the latter is mediated by contextual factors in Polish (esp. contrast). The general picture of the sloppy reading of overt pronouns which emerges from the discussion is thus that it is in principle available not only with pronominal clitics, but also with phrasal pronouns, including the full 
(morphologically largest) forms. I have suggested that this results from third person pronouns having the NumP representation, in addition to PersP, regardless of their morphological complexity. Such a representation can be interpreted as property anaphora, yielding the required reading.

It should also be noted that the sloppy reading can be manifested by deep anaphoric null arguments such as the ones used without linguistic antecedents (see Kasai 2014 and Tomioka 2014b for a discussion of Japanese and Section 2 above for data from Polish) and even in Japanese, a language which makes argument drop widely available, overt pronouns can also have the sloppy reading (see Tomioka 2014b). What all this shows is that the empirical picture is much more complex than it seems at first and that data from a broader spectrum of languages and contexts are needed if we are to be successful in disentangling all the relevant factors and developing an optimal theoretical approach.

\section{References}

BAILYN John Frederick (2017). Against a VP ellipsis account of Russian verb-stranding constructions. In Studies in Japanese and Korean Linguistics and beyond, Alexander Vovin (ed.), 93-109. Leiden: Brill.

BošKović Željko (2018). On pronouns, clitic doubling, and argument ellipsis: Argument ellipsis as predicate ellipsis. English Linguistics 35, 1-37.

Cardinaletti Anna, Starke Michal (1999). The typology of structural deficiency: A case study of the three classes of pronouns. In Eurotyp. Volume 5/Part 1: Clitics in the Languages of Europe, Henk van Riemsdijk (ed.), 145-234. Berlin, New York: De Gruyter Mouton.

Centnarowska Bożena (2003). On pronominal clusters in Polish. In Investigations into Formal Slavic Linguistics: Contributions of the Fourth European Conference on Formal Description of Slavic Languages - FDSL IV held at Potsdam University, November 28-30, 2001, Peter Kosta, Joanna BŁaszczak, Jens Frasek, Ljudmila Geist, Marzena Żygis (eds.), 13-30. Frankfurt am Main: Peter Lang.

Centnarowska Bożena (2004). The scale of pronominal strength in Polish: An OT analysis of unstressed and weak pronouns. Poznań Studies in Contemporary Linguistics 39, 39-57.

Cheng Hsu-Te Johnny (2013). Argument ellipsis, classifier phrases, and the DP parameter. Storrs, CT: University of Connecticut, Ph.D. dissertation.

Chierchia Gennaro (1998). Reference to kinds across languages. Natural Language Semantics 6, 339-405.

Cyrino Sonia, Lopes Ruth (2016). Null objects are ellipsis in Brazilian Portuguese. The Linguistic Review 33, 483-502.

Duguine Maia (2014). Argument ellipsis: A unitary approach to pro-drop. The Linguistic Review 31, 515-549.

Elbourne Paul (2005). Situations and Individuals. Cambridge, MA: MIT Press. 
Elbourne Paul (2013). Definite Descriptions. Oxford: Oxford University Press.

Franks Steven (2013). Orphans, doubling, coordination, and phases: On nominal structure in Slovenian. Slovenski jezik - Slovene Linguistic Studies 9, 55-92.

Franks Steven (2016). Clitics are/become Minimal(ist). In Formal Studies in Slovenian Syntax: In Honor of Janez Orešnik, Franc Lanko MARušič, Rok ŽAucer (eds.), 91128. Amsterdam: John Benjamins.

Gribanova Vera (2013a). Verb-stranding Verb Phrase ellipsis and the structure of the Russian verbal complex. Natural Language and Linguistic Theory 31, 91-136.

Gribanova Vera (2013b). A new argument for verb-stranding Verb Phrase ellipsis. Linguistic Inquiry 44, 145-157.

Heim Irene (1991). Artikel und definitheit [Articles and definiteness]. In Semantik: Ein internationales Handbuch der zeitgenössischen Forschung, Arnim von STECHOW, Dieter Wunderlich (eds.), 487-535. Berlin: de Gruyter.

Hoji Hajime (1998). Null object and sloppy identity in Japanese. Linguistic Inquiry 29, 127-152.

HuANG C.-T. James (1987). Remarks on empty categories in Chinese. Linguistic Inquiry $18,321-337$.

HuAng C.-T. James (1991). Remarks on the status of null objects. In Principles and Parameters in Comparative Grammar, Robert FreIDIN (ed.), 56-76. Cambridge, MA: MIT Press.

Jung Hakyung, Migdalski Krzysztof (2015). On the degrammaticalization of pronominal clitics in Slavic. In Formal Approaches to Slavic Linguistics: The First Berkeley Meeting 2014 (Michigan Slavic Materials, 61), Małgorzata SzajBel-Keck, Roslyn Burns, Darya Kavitskaya (eds.), 143-162. Ann Arbor, MI: Michigan Slavic Publications.

Kasai Hironobu (2014). On the nature of null clausal complements in Japanese. Syntax 17, 168-188.

KIm Soowon (1999). Sloppy/strict identity, empty objects, and NP ellipsis. Journal of East Asian Linguistics 8, 255-284.

KurAFUj Takeo (2018). A choice function approach to null arguments. Linguistics and Philosophy 42, 3-44.

LANDAU Idan (2018). Missing objects in Hebrew: Argument ellipsis, not VP ellipsis. Glossa 3, 1-37.

LANDAU Idan (2020). On the nonexistence of verb-stranding VP-ellipsis. Linguistic Inquiry 51, 341-365.

Lowenstamm Jean (2008). On little n, $\sqrt{ }$, and types of nouns. In Sounds of Silence: Empty Elements in Syntax and Phonology, Jutta Hartmann, Veronika Hegedüs, Henk van Riemsdijk (eds.), 105-144. Amsterdam: Elsevier.

McShane Marjorie J. (1999). The ellipsis of accusative direct objects in Russian, Polish and Czech. Journal of Slavic Linguistics 7, 45-88.

Merchant Jason (2013). Diagnosing ellipsis. In Diagnosing Syntax, Lisa Lai-Shen Cheng, Norbert Corver (eds.). Oxford: Oxford University Press.

Merchant Jason (2018). Verb-stranding predicate ellipsis in Greek, implicit arguments, and ellipsis-internal focus. In A Reasonable Way to Proceed: Essays in Honor of Jim McCloskey, Jason Merchant, Line Miknelsen, Deniz Rudin, and Kelsey Sasaki (eds.), 229-269. University of California eScholarship. 
Migdalski Krzysztof (2016). Second Position Effects in the Syntax of Germanic and Slavic Languages. Wrocław: Wydawnictwo Uniwersytetu Wrocławskiego.

OKU Satoshi (1998). A theory of selection and reconstruction in the Minimalist perspective. Storrs, CT: University of Connecticut, Ph.D. dissertation.

Otani Kazuyo, Whitman John (1991). V-raising and VP-ellipsis. Linguistic Inquiry $22,345-358$.

Perlmutter David, Orešnik Janez (1973). Language-particular rules and explanation in syntax. In A Festschrift for Morris Halle, Stephen R. Anderson, Paul Kiparsky (eds.), 419-459. New York, NY: Holt, Rinehart and Winston.

RUdA Marta (2021). Polish personal pronouns: $\left[_{\text {PersP }} \sim\right.$ Pers $\left[_{\text {NumP }}\right.$ Num [n]]] and $\left[_{\text {NumP }}\right.$ Num [n]]. Studies in Polish Linguistics 16(1), 23-40.

RudA Marta (2017). On the Syntax of Missing Objects. A Study with Special Reference to English, Polish, and Hungarian. Amsterdam/Philadelphia: John Benjamins.

Runić Jelena (2013). A new look at clitics: Evidence from Slavic. In Formal Approaches to Slavic Linguistics: The Third Indiana Meeting 2012, Steven Franks, Markus Dickinson, George Fowler, Melissa Witcombe, Ksenia Zanon (eds.), 275-288. Ann Arbor, MI: Michigan Slavic Publications.

SAito Mamoru (2007). Notes on East Asian argument ellipsis. Language Research 43, 203-227.

SAкамото Yuta (2019). Overtly empty but covertly complex. Linguistic Inquiry 50, $105-136$.

SAUERLAND Uli (2007). Flat binding: Binding without sequences. In Interfaces + Recursion = Language?, Uli SAUERLAND, Hans-Martin GärTner (eds.), 197-254. Berlin: Mouton de Gruyter.

ŞEnER Serkan, TAKahashi Daiko (2010). Ellipsis of arguments in Japanese and Turkish. Nanzan Linguistics 6, 79-99.

TAKahashi Daiko (2008). Quantificational null objects and argument ellipsis objects and argument ellipsis. Linguistic Inquiry 39, 307-326.

TAKahashi Daiko (2020). Derivational argument ellipsis. The Linguistic Review 37, 47-74.

TANCredi Christopher Damian (1992). Deletion, deaccenting and presupposition. Cambridge, MA: Massachusetts Institute of Technology, Ph.D. dissertation.

TоміокA Satoshi (2003). The semantics of Japanese null pronouns and its cross-linguistic implications. In The Interfaces: Deriving and Interpreting Omitted Structures, Kerstin Schwabe, Susanne Winkler (eds.), 321-339. Amsterdam: John Benjamins.

TomiokA Satoshi (2014a). Micro-parameters in discourse pro-drop languages: Comments on 'Born empty' by Yen-hui Audrey Li. Lingua 151, 69-77.

Tоміока Satoshi (2014b). Remarks on missing arguments in Japanese. In Proceedings of FAJL 7: Formal Approaches to Japanese Linguistics, Shigeto KaWAHARA, Mika IgARAshi (eds.), 251-263. Cambridge, MA: MIT Press.

WeCHSLER Stephen (2006). Why are the lazy so agreeable? In Between 40 and 60 Puzzles for Krifka, Hans-Martin Gärtner, Sigrid Beck, Regine EcKardt, Renate Musan, Barbara Stiebels (eds.). Berlin: ZAS.

Willim Ewa (2012). On the feature valuation/interpretability biconditional in Minimalist Theory. The case of (un)interpretable gender. In Sound, Structure and Sense. Studies in Memory of Edmund Gussmann. Eugeniusz Cyran, Henryk Kardela, Bogdan SzymaneK (eds.), 761-806. Lublin: Wydawnictwo KUL. 
Witkoś Jacek (1998). The Syntax of Clitics. Steps towards a Minimalist Account. Poznań: Motivex.

Marta Ruda

Instytut Filologii Angielskiej UJ

al. Adama Mickiewicza 9A, 31-120 Kraków

Poland

marta.ruda[at]uj.edu.pl 